\title{
Optoelectronics in Japan: A Market Evaluation of Government High-Technology Policy
}

\author{
Gary R. Saxonhouse* \\ University of Michigan, Ann Arbor, MI, USA
}

Manage. Decis. Econ. 18: 177-193 (1997)

No. of Figures: 2 No. of Tables: 7 No. of References: 22

\section{INTRODUCTION}

In survey after survey of US firms, the business environment is viewed as the greatest area of disadvantage for high-technology firms. In this area such surveys suggest that American high-technology firms are at their greatest disadvantage when compared with firms operating in Japan. It is argued that the role the Japanese government plays within the Japanese economy puts American firms at a particular disadvantage when competing globally with Japanese firms. The most commonly cited Japanese government practices include 'financial support ..... including R\&D grants/credit, favorable tax treatment and low interest rate loans to finance exports, R\&D and investment' (US Department of Commerce, 1994, p. V-8).

This particular characterization of Japanese government practices comes from the responses of firms included in the US Department of Commerce's assessment of the US optoelectronics industry. When these firms were asked, however, to provide specific examples of such practices, the US Department of Commerce notes many companies mentioned MITI of Japan, but few gave specific examples of how MITI programs benefitted the optoelectronics industry' (p. V-8). This paper attempts to fill this gap. The first section of the paper

\footnotetext{
* Correspondence to: Gary R. Saxonhouse, Department of Economics, University of Michigan, Ann Arbor, MI, 481091220, USA.
}

discusses the distinctive characteristics of the optoelectronics industry and why a government might want to promote its competitiveness. The second section catalogues aid given by the Japanese government and contrasts these programs with US government activities. In the final section of the paper, the impact of Japanese government programs on the competitiveness of Japanese and US firms is assessed.

\section{OPTOELECTRONICS AND THE CASE FOR GOVERNMENT INTERVENTION}

The primary information technologies in the twentieth century rely on electrons to transmit information. In common with electrons, particles of light called photons can also be used to transmit information. Photons offer significant advantages over electrons including greater speed, capacity, energy efficiency, and immunity to electromagnetic interference. Because electrons carry a charge and a mass, they are slower and must be guided along copper wires or cables that, in turn, must be covered with a protective coating in order to present interference or crosstalk. Electrons also require expensive amplifiers to boost signal transmission over long distances. By contrast, photons do not have a mass or charge to restrict their travel or necessitate frequent amplification. Since light beams to not interact with one another, unlike copper cables, they can be super- 
imposed onto one another providing greater information-carrying capacity. In consequence, light has the potential to unblock some of the bottlenecks that are hindering electronics, such as pin congestion on integrated circuits, tangled tracks on printed circuit boards, interference and signal degradation (The Economist, 1991). To date, the best-known breakthrough in optoelectronics include the invention of the laser (Light Amplification by $\underline{\text { Stimulated }}$ Emission of Radiation) in the late $1950 \mathrm{~s}$ and the invention of the optical fiber in the 1970s. Some applications of optoelectronic technologies are listed in Table 1. Looking to the future, the Washingtonbased Optoelectronics Industry Development Association projected in 1994 that global markets enabled by optoelectronics technologies will grow at an average annual rate of almost $10 \%$ over the next twenty years, reaching $\$ 460$ billion in size by the middle of the second decade of the twenty-first century (Optoelectronics Industry Development Association, 1994).

That global demand for optoelectronics-enabled equipment will grow relatively rapidly over the next twenty years does not mean that governments in East Asia, North America and Europe should be promoting the development of this industry. The argument that governments should always promote growth sectors is equivalent to saying that private markets systematically undervalue future growth prospects (Grossman, 1990). There is very little evidence to suggest that this is so and much evidence to the contrary. Even the traditional arguments for market failure including the presence of economies of scale, learning by doing, externalities and capital market imperfections may not provide a rationale for government intervention (Mas-Colell, Whinston and Green, 1995). For example, suppose the benefits of knowledge creation cannot be fully appropriated by the Japanese economy as a whole any more than they can be appropriated by an individual Japanese firm. Under these conditions, that is, with knowledge flowing across national boundaries, promotion of optoelectronics by the Japanese government, even in the presence of market failure, may be difficult to justify. Similarly, suppose optoelectronics is characterized by very large-scale/learning economies. Should Japanese government support be forthcoming if its end result is simply to allow optoelectronics to bid away scarce resources from related fields also characterized by very large-scale/learning economies? Finally, even if it bid no resources away from other similarly situated industries, Japanese
Table 1. Optoelectronic Product Categories

I. Fiber-optic communications

Transmission

Multiplexers

Switches

Cable TV distribution

Transmitter/receiver modules

Optical modulators

Amplifiers

Connectors

Fibers

II. Fiber-optic information equipment

Optical processing units

Faxes

Image processing

Bar code readers

Printers

Memory/storage devices

Displays

Interconnects

III. Industrial/medical equipment.

Machine vision

Optical test and measurement

Non-laser medical equipment

Night vision surveillance

Laser processing equipment

Lasers

IV. Non-military transportation equipment

Automotive interior displays

Optical gyroscopes

Cockpit displays

Fly by light

Traffic control systems

\section{Military equipment}

Fiber-optic ground/satellite communications

Laser weapons

Munition guidance

VI. Consumer equipment

TVs

Appliance displays

Home faxes

CD players

Video cameras

VII. Subsystems/components

Photo detectors

Semiconductor light sources

Hybrid optical devices

Source: US Department of Commerce (1994).

government aid could lower rather than raise national welfare if such policies promote retaliation from Japan's trading partners (Krugman, 1987).

There is only scattered, inconclusive evidence as to whether the present optoelectronics technologies are fraught with large economies of scale. The US 
Department of Commerce assessment of the US optoelectronics industry found that, defense contractors apart, the overwhelming majority of the firms included in their survey did not consider themselves to be the prime source for any optoelectronic product or technology (US Department of Commerce, 1994, p. IV-25). With the important exception of optical glass, these firms, in turn, relied on a variety of sources for the parts, subcomponents or raw materials in their optoelectronic products. ${ }^{1}$

It is equally difficult to find conclusive evidence on the presence or absence of large economies of scale in the research and development of new optoelectronics technologies. In Figs 1 and 2, data on the size of $R \& D$ activities for each of 33 optoelectronics product categories are presented organized both by the number of professional employees engaged in R\&D activities and by the size of the $R \& D$ investment made. Out of the 33 product categories, for only solar cells, optical connectors, ROM optical disks, optical printers and optical telecommunications systems does more than $50 \%$ of R\&D activity occur in programs larger than 50 employees and for only two, ROM optical disks and optical printers, does more than $50 \%$ of R\&D activity occur in programs larger than 125 employees. These results change only marginally if the criterion used is size of $R \& D$ investment. As seen in Fig. 2, in addition to ROM optical disks, only displays, optical fibers, write-once optical disks and laser processing equipment have more than $50 \%$ of their R\&D activity supported by investments of more than $\$ 7.5$ million.

Despite the concentration of $R \& D$ activity in the optoelectronics industry in small-scale programs, in the absence of some outcome measure, such as patents, it is still difficult to conclude from this evidence that large economies of scale are not present. Moreover, among the optoelectronic products where $R \& D$ activity is not concentrated in small-scale programs, displays, printers and optical fibers together account for approximately one-third of the sales of all optoelectronics products globally. In 1993, the Japanese optoelectronics industry produced $\$ 5.6$ billion in printers, $\$ 4.8$ billion in displays and $\$ 1.3$ billion in optical fibers (Hikari sangyo no doko, 1994, pp. I-18-I-32).

However difficult it may be to venture even a guess about the prevalence of scale economies in optoelectronics in the absence of comprehensive data on outputs and inputs, discussing the extent of externalities and their national specificity is still more hazardous. About all that can be said is that the science underlying optoelectronics is the product of international efforts and that industry scientists in Japan, the United States and Europe are all active participants in major international conferences and significant contributors to many of the most important optoelectronics-related scientific journals. ${ }^{2}$ As can be seen from Table 2, the Conference on Laser and Electro-Optics (CLEO), draws a very large number of scientists from both the United States and Japan. While American scientists presented four times as many papers as Japanese scientists at CLEO in 1992, there is considerable variation in the relative contributions of Japanese and American scientists in the numerous subdisciplines of optoelectronics. For example, as seen in Table 3, an analysis of five leading electrical engineering journals published in the United States found more than half the papers published on optoelectronic integrated circuits were by Japanese scientists. Significantly, 38 out of 39 of these papers were authored by Japanese scientists working for Japanese companies. In con-

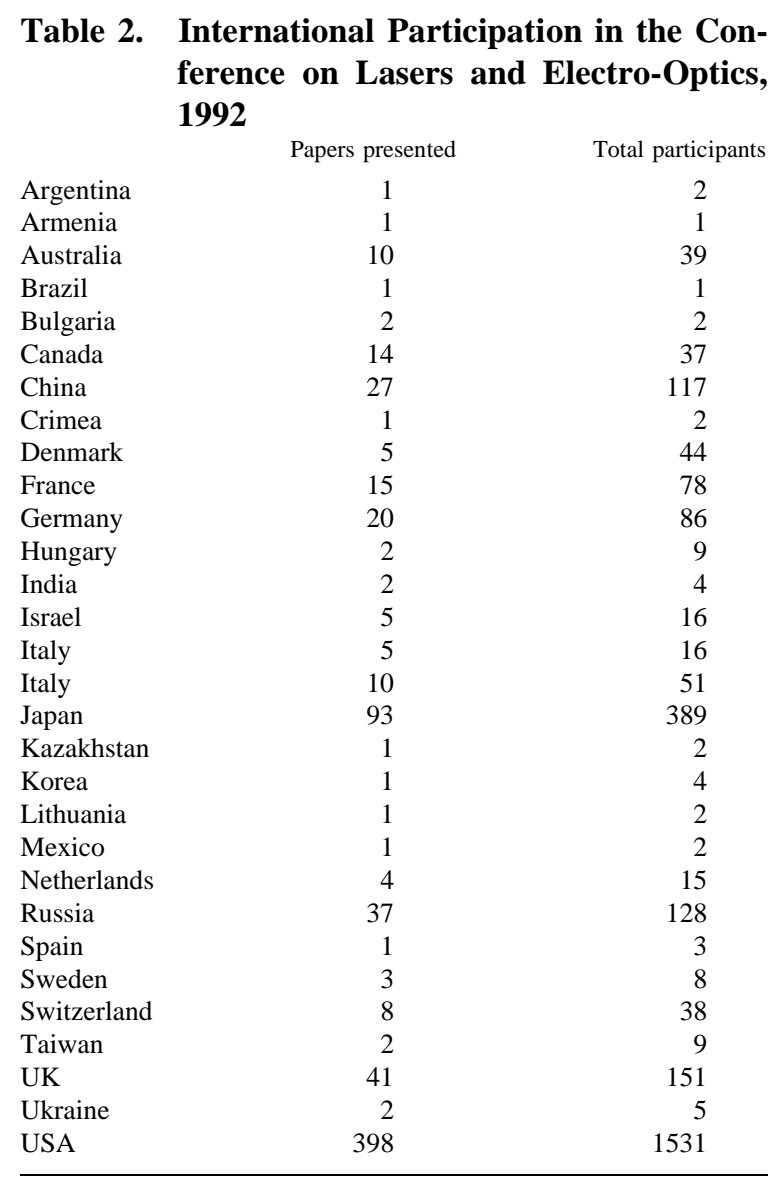

Source: Hikari sangyo no doko (1994). 
Figure 1a: Distribution of R\&D Personnel in the Japanese Optoelectronics Industry by Program Size

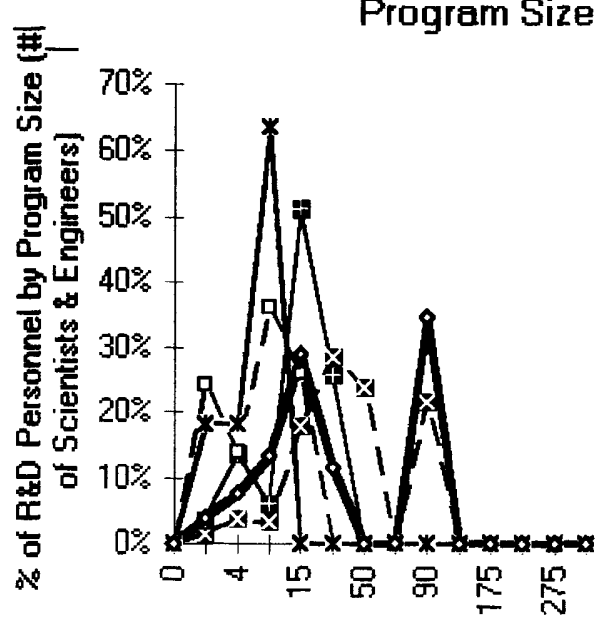

Source: Hikari sanguo gïutsu DOKO [Tokyo, 1994] shinkokai, HIKARI SANGYO no

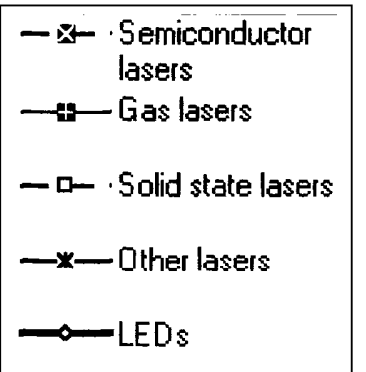

Figure 1. Distribution of R\&D personnel in the Japanese optoelectronics industry by program size. (Source: Hikari sangyo no doko, 1994.)

Source: Hikari sangyo gijutsu
Figure 1b: Distribution of R\&D Personnel in the Japanese Optoelectronics Industry by Program Size
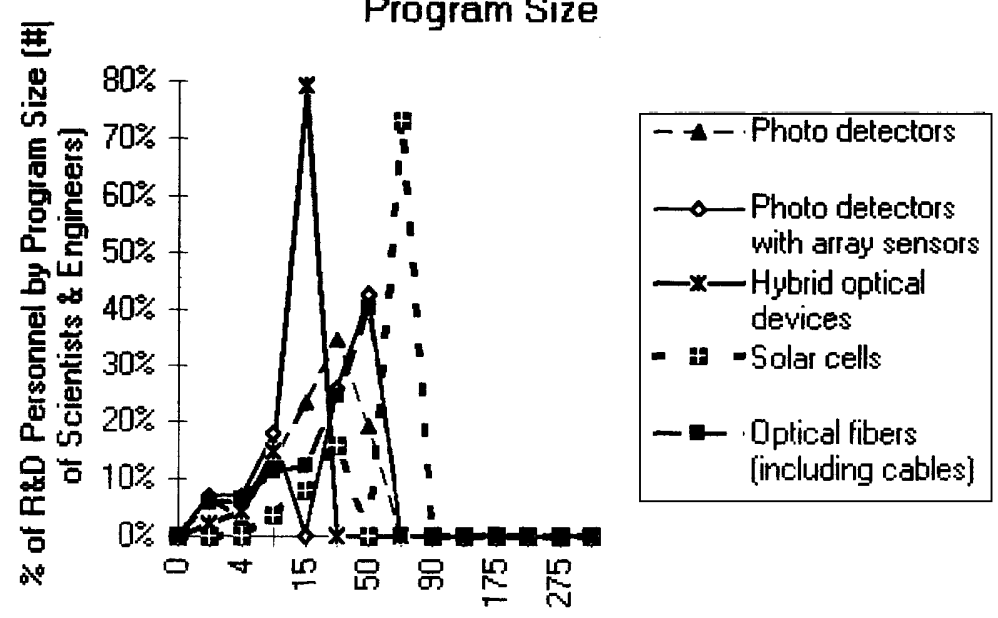

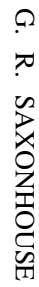
shinkokai, HIKARI SANGYO no DOKO [Tokyo, 1994] 
Figure 1c: Distribution of R\&D Personnel in the Japanese Optoelectronics Industry by Program Size

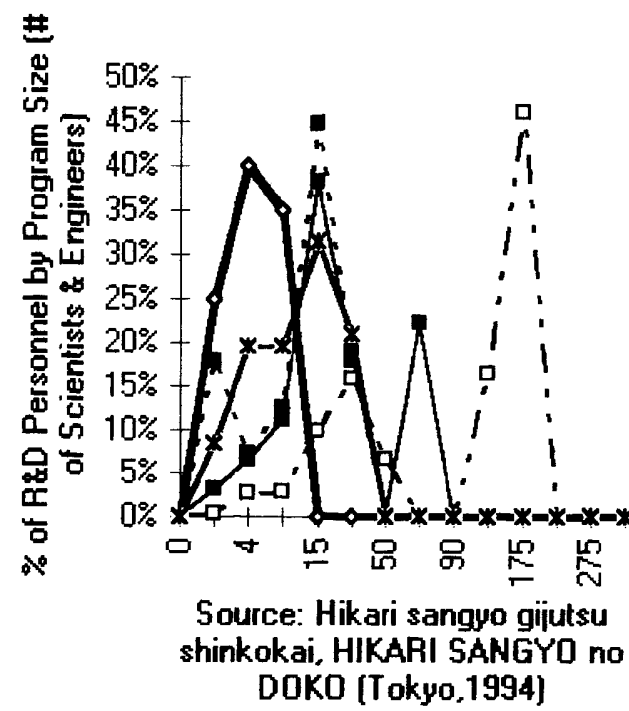
DOKO [Tokyo.1994]

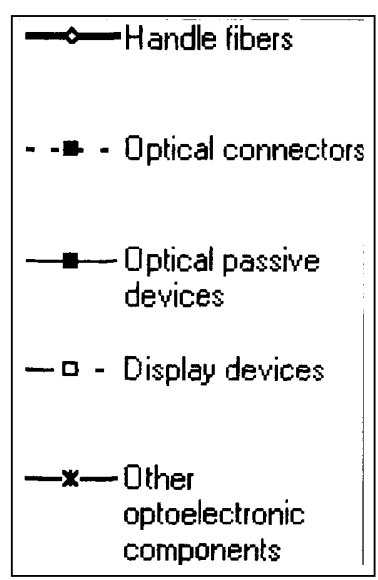

Figure 1. (continued)
Figure 1d: Distribution of R\&D Personnel in the Japanese Optoelectronics Industry by Program Size

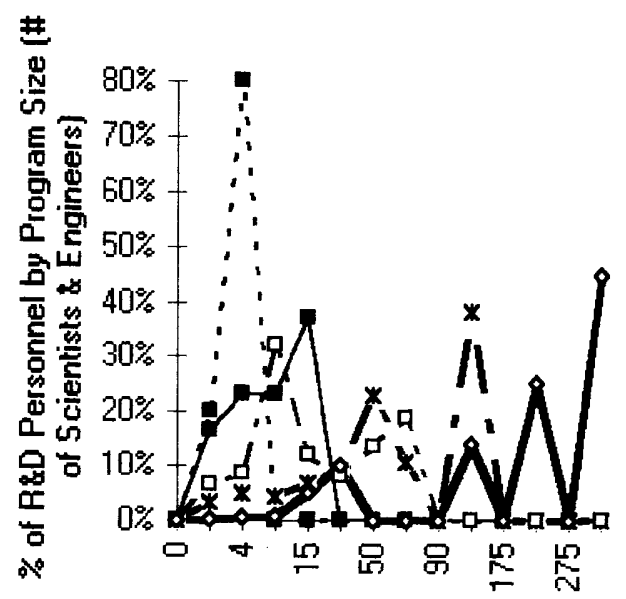

Source: Hikari sangyo gijutsu shinkokai, HIKARI SANGYO no DOKO [Tokyo, 1994]

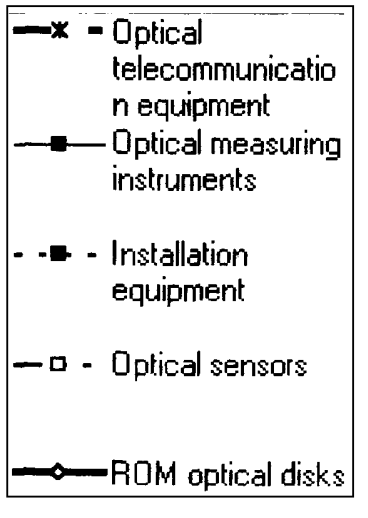

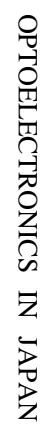


Figure 1e: Distribution of R\&D Personnel in the Optoelectronics Industry by Program Size

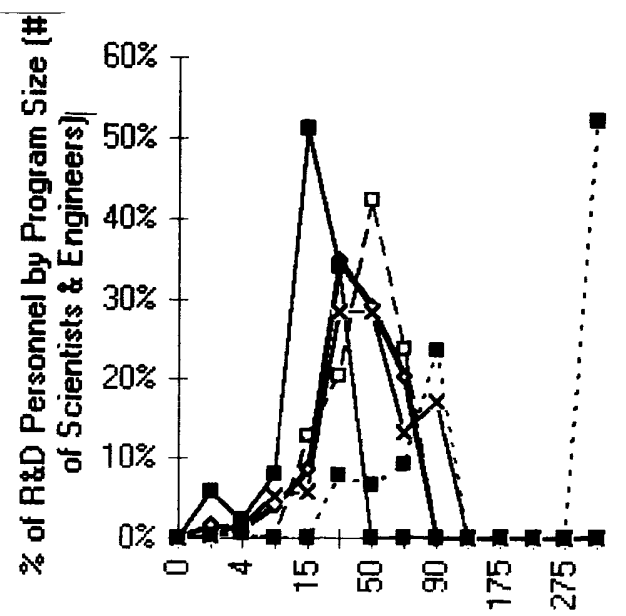

Source: Hikari sangyo gijutsu shinkokai. HIKARI SANGYO no DOKO [Tokyo, 1994)
Figure 1f: Distribution of R\&D Personnel in the Japanese Optoelectronics Industry by

$$
\text { Program Size }
$$

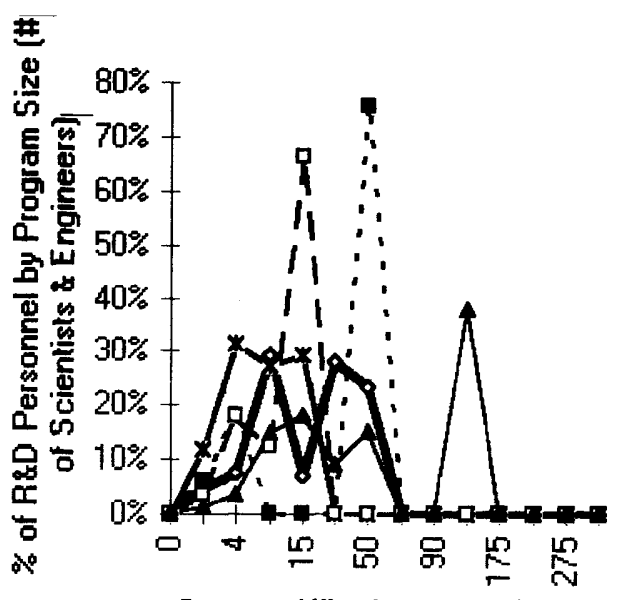

Source: Hikari sangyo gijutsu shinkokai, HIKARI SANGYO no DOKO [Tokyo, 1994]

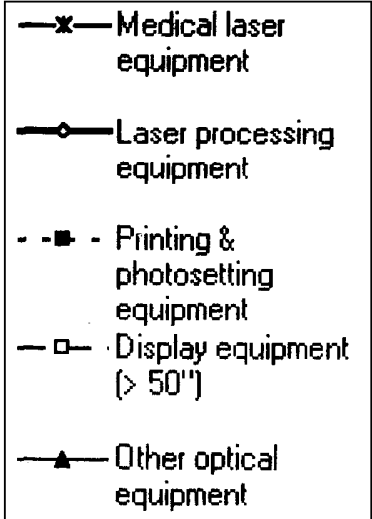

0
0
0
2
$x$
0
$z$
0
0
0
II

Figure 1. (continued) 


\section{Figure 1g: Distribution of R\&D Personnel in the Japanese Optoelectronics Industry by Program Size}

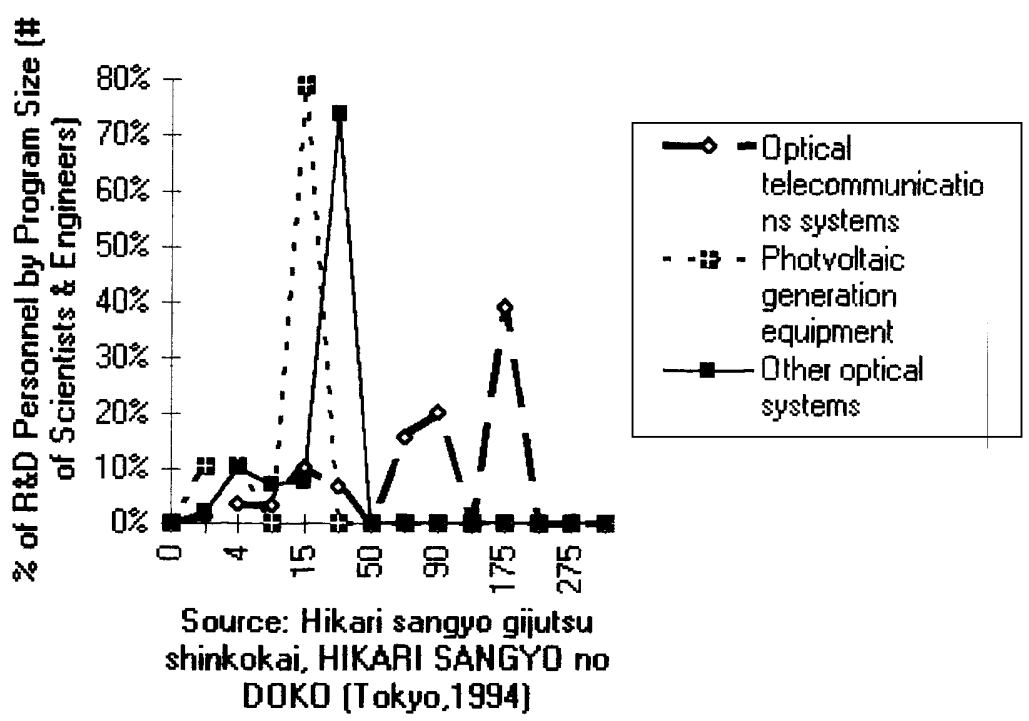

Figure 1. (continued)

trast, company-based scientists accounted for 16 out of 24 of the American papers and only two out of eight of the European papers.

\section{GOVERNMENT SUPPORT FOR THE JAPANESE OPTOELECTRONICS INDUSTRY}

In Japan, government funding of private companybased optoelectronics $R \& D$ is done almost exclusively under the auspices of the Ministry of International Trade and Industry (MITI) in the context of a number of cooperative governmentbusiness research projects, the first of which began in 1979 with the establishment of MITI's Optical Measurement and Control Systems project. ${ }^{3}$ This project ran for seven years with $\$ 77$ million in government funding. The project joined together 16 Japanese companies with researchers from MITI's Electro-Technical Laboratory. Included among these 16 firms were such large Japanese companies as Toshiba, NEC, Hitachi, Fujitsu, Matsushita, Mitsubishi and Oki. In 1981 as part of this project the Optoelectronics Joint Research Laboratory (OJRL) began operations. Each of the 16 participating companies lent research personnel to staff the joint laboratory even while they continued to receive funding for project-related work at their own laboratories. At its peak of operation in 1984 and 1985 this joint laboratory comprised no more than 50 scientists and engineers (Hayashi, Hirano and Yoshifumi, 1989). In an industry whose optoelectronics research programs employed some 5500 scientists and engineers in the mid-1980s this would have to be considered a relatively small research project.

When the ORJL, whose chief purpose came to be advancing technology in fiber-optic local area network systems using as a main tool optoelectronic semiconductors, disbanded in 1986, MITI promoted the establishment of the Optoelectronic Technology Research Corporation (OTRC) in its place. Unlike the $100 \%$ MITI-funded project that preceded it, the tenyear $\$ 82$ million OTRC budget which also included the sponsorship of a joint research laboratory to focus on optoelectronic semiconductors was $70 \%$ funded by the member companies themselves. While the OTRC project is comparable in scale to its predecessor, its joint laboratory included on its roster no more than 15 scientists on loan from the participating companies.

There is almost no prospect that Japanese government funding for optoelectronics research and development will change dramatically in the future. The growing importance of MITI's Real World Computing (RWC) program, however, has meant 
Figure 2a: Distribution of R\&D Investment in the Japanese Optoelectronics Industry by Program Size
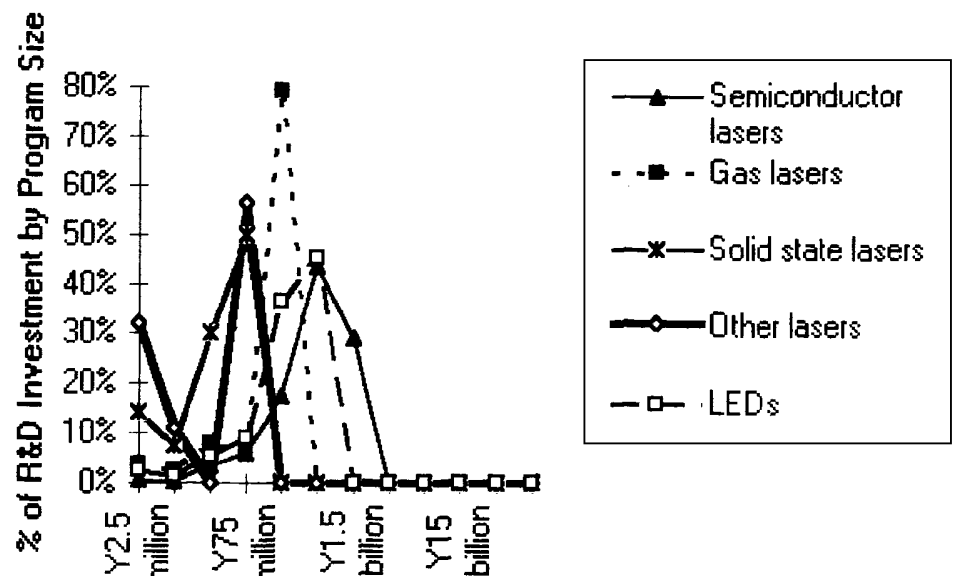

Source: Hikari sangyo gijutsu shinkokai, HIKARI SANGYO no DOKO [Tokyo, 1994]
Figure $2 b$ : Distribution of R\&D Investments in the Japanese Optoelectronics Industry by Program Size

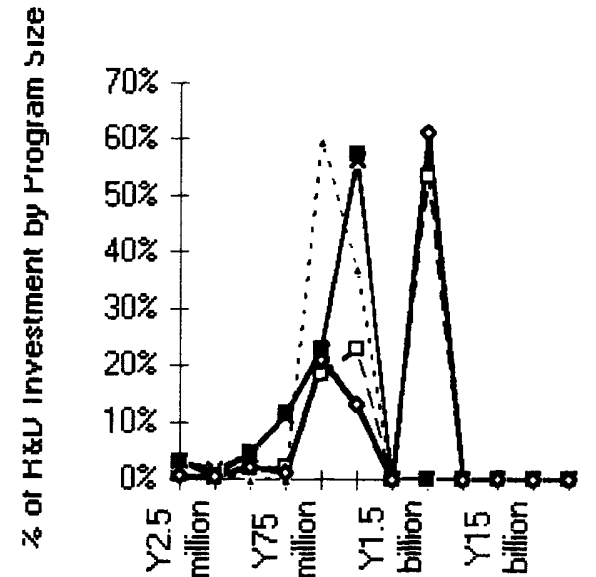

- $\square$ - Photo detectors:

- $x$-Photo detector: with array sensors Hybrid optical devices

$\longrightarrow$ Solar cells

- Optical fibers (including caloles)

Figure 2. Distribution of R\&D investment in the Japanese optoelectronics industry by program size. (Source, Hikari sangyo no doko, 1994). 
Figure 2c: Distribution of R\&D Investment in the Japanese Optoelectronics Industry by

$$
\text { Size }
$$

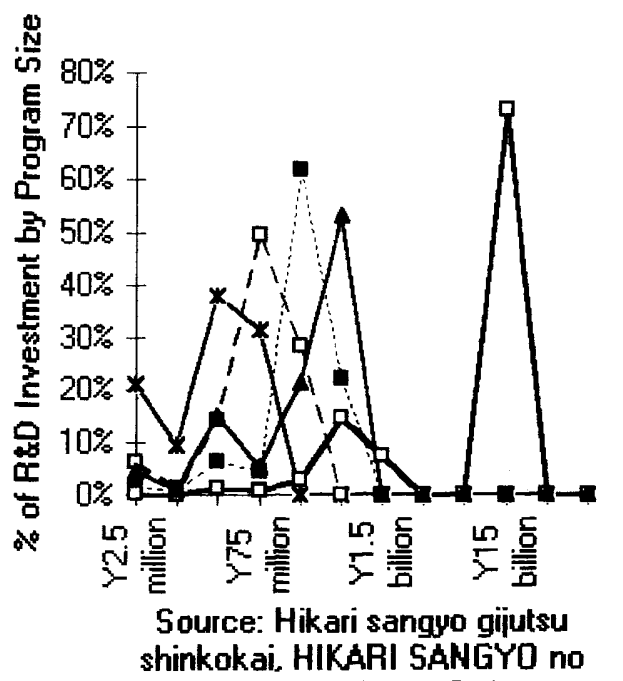

DOKO (Tokyo, 1994)
Figure 2d: Distribution of R\&D Investment in the Japanese Optoelectronics Industry by Program Size

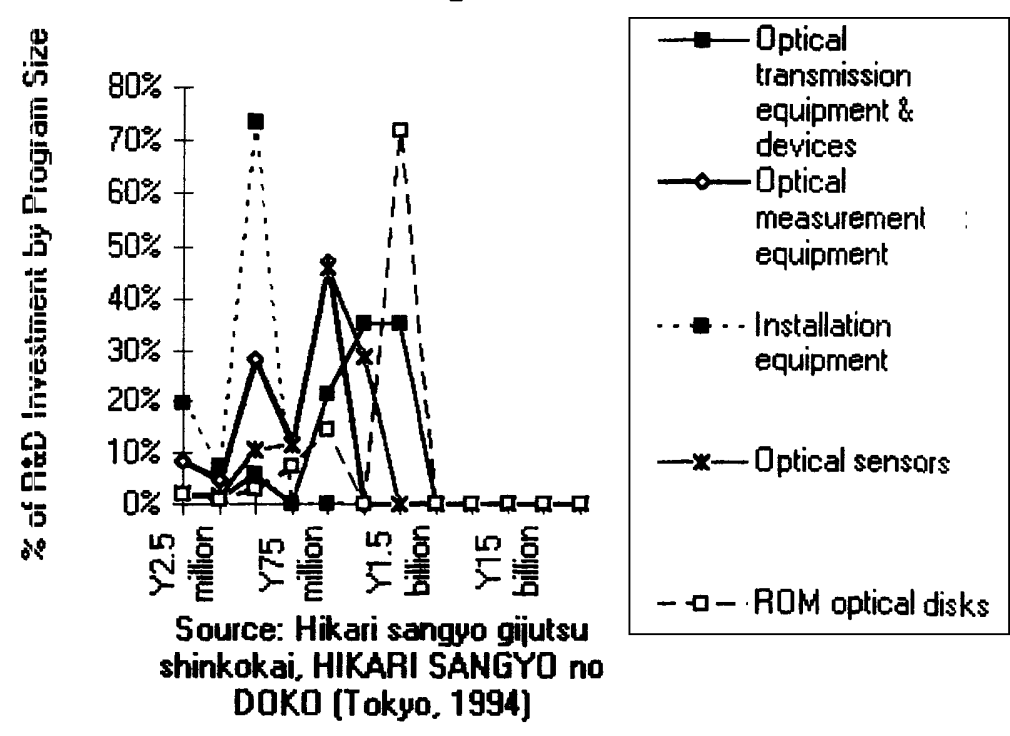

Figure 2 (continued) 
Figure 2e: Distribution of R\&D Investment in the Japanese Optoelectronics Industry by Program Size

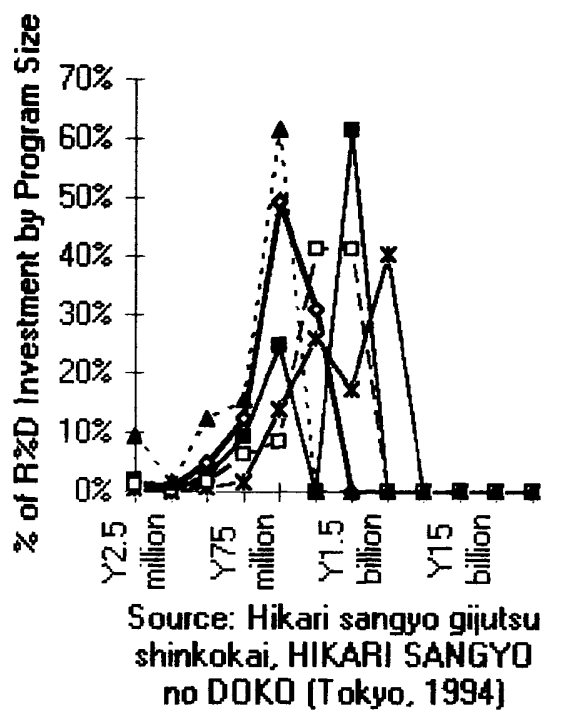

Figure 2f: Distribution of R\&D Investment in the Japanese Optoelectronics Industry by Program Size

$\rightarrow-$ Write once optical
disks
$\rightarrow$ Rewritable optical
disks
$-x$ - Other optical disks
$-\square-$ Optical printers
$\cdots-$ Laser scanners
[including bar-
code readers]

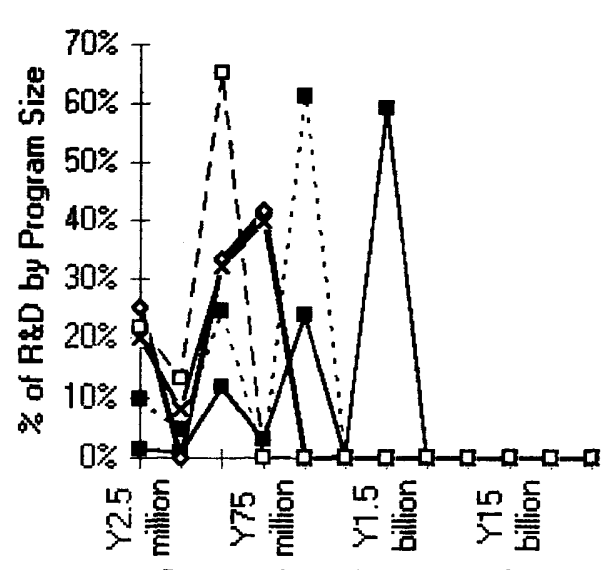

Source: Hikari sangyo gijutsu shinkokai, HIKARI SANGYO no DOKO (Tokyo, 1994)

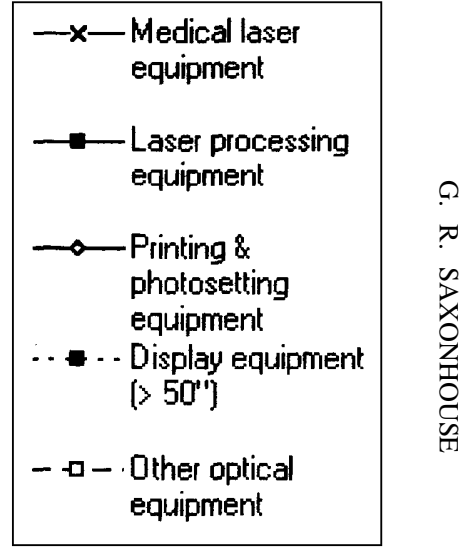

Figure 2 (continued) 


\section{Figure 2q: Distribution of R\&D Investments in the Japanese Optoelectronics Industry by Program Size}

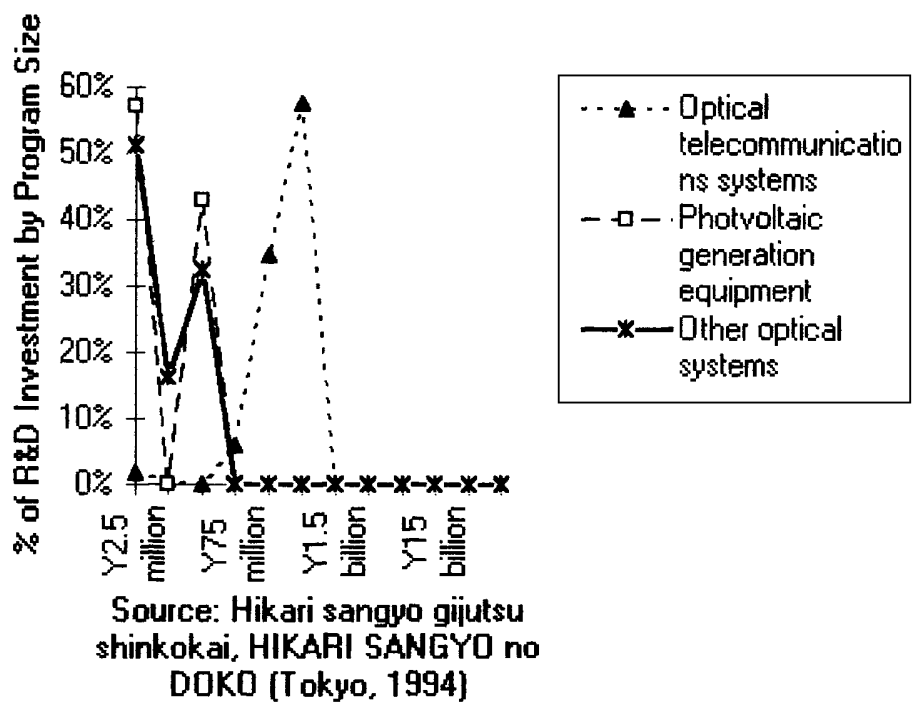

Figure 2 (continued)

that support has returned at least to the levels that were characteristic of the late 1970s through the mid1980s. The Real World Computing project has become MITI's major initiative in support of the development of basic computer technologies following the end of its highly controversial Fifth Generation Computer program which in Japan, in retrospect, is viewed as having been fatally flawed in its conception (Saxonhouse, 1993). The very title of MITI's new project is meant to distinguish it sharply from the failure of its previous initiative in basic computer technology. One of the distinguishing features of the RWC program is its support of optical computing in the interest of both energy-saving and miniaturization. Fujikura, Fujitsu, Furukawa Electric,

\begin{tabular}{lccccccc}
\hline Table 3. & $\begin{array}{l}\text { Scientific } \\
\text { Integrated } \\
\text { Area }\end{array}$ & $\begin{array}{c}\text { Papers } \\
\text { Circuits }\end{array}$ & on & \multicolumn{3}{c}{$\begin{array}{c}\text { Optoelectronic } \\
\text { by }\end{array}$} & $\begin{array}{c}\text { Geographical } \\
\end{array}$ \\
& 1983 & 1984 & 1985 & 1986 & 1987 & 1988 & Total \\
U.S. & 2 & 3 & 5 & 5 & 2 & 2 & 24 \\
Japan & 5 & 5 & 8 & 12 & 5 & 4 & 39 \\
Europe & 1 & 0 & 0 & 4 & 2 & 1 & 8 \\
Rest of World & 0 & 0 & 0 & 1 & 0 & 0 & 1 \\
Total & 8 & 8 & 13 & 22 & 9 & 12 & 72 \\
\hline
\end{tabular}

Source: Seidenberg (1992) The five journals used in this analysis include Journal of Lightwave Technology; IEEE Journal of Quantum Electronics; IEEE Electronic Device Letters; Electronics Letters, Applied Physics Letters.
Hitachi, Matsushita, Mitsubishi Electric, NEC, Nippon Sheet Glass, Oki, Sanyo, Sumitomo Electric and Toshiba are dividing a total of $\$ 70$ million in support over a ten-year period as principal research project contractors (Real World Computing Partnership, 1994). Under the rubric of the RWC program a major femtosecond project was also initiated in $1995 .^{4}$

Government support of the Japanese optoelectronics industry is not limited to direct funding. While Japanese tax policy since the 1970s has been more interested in harmonizing rather than differentiating tax rates across sectors, high-technology sectors do benefit from a variety of tax credits and special depreciation allowances in the Japanese tax code (Saxonhouse, 1983). In common with the rest of Japanese industry, optoelectronics companies receive a $20 \%$ tax credit for R\&D expenditures over and above a company's previous highest level of research and development expenditures since 1967. This credit is limited to $10 \%$ of a Japanese company's income tax liability. This particular limitation on the size of the tax credit and the requirement that only the single highest previous year of R\&D expenditures be used as the base in calculating it instead of a moving average, makes this provision of the Japanese tax code substantially less generous than its American counterpart. ${ }^{5}$ In consequence, the generic US research and development tax credit is estimated to be 
$150 \%$ larger than the Japanese tax credit as a proportion of research and development expenditures (Sangyo zeisei handobukku, 1994).

There are provisions of the Japanese tax code promoting research and development, however, that are more specific than the general research and development tax credit. Included among these is the Key Technologies Research and Development Tax Credit (Kiban gijutsu kaihatsu sokushi zeisei). The list of research eligible for this credit includes 132 technologies. The tax credit is equal to $7 \%$ of research and development investment made in any of the eligible technologies up to $15 \%$ of the corporate income tax liability. The limitation on the tax credit is not independent, however, of the limit on the general research and development tax credit. Among 132 technologies eligible for he Key Technological Research and Development Tax Credit are 25 that are optoelectronics-related. These technologies are listed in Table 4. The length of this list suggests that along with semiconductors, robotics, new materials, biotechnology and space science, optoelectronics is the beneficiary of special tax advantages, when compared with most other high technology industries. The Ministry of Finance

\section{Table 4. Optoelectronic Technologies Eligible for the Key Technologies Research and Development Tax Credit, 1994}

\author{
Laser DNA microinjector \\ Laser bean fluid particle \\ counter \\ LED beam particle dispersion \\ counter \\ Laser bean particle dispersion \\ counter \\ Laser oscillation testing \\ equipment \\ Variable wide-bank laser \\ Optical spectrum analyzer \\ Solar cell testing device \\ Optical fiber signal loss testing \\ equipment \\ Optical recording media groove \\ production device \\ Ultraprecise photoelectric \\ forming apparatus \\ Vacuum deposition chamber \\ for optical uses \\ Spectrum analyzer using 0.005 \\ nanometer laser
}

Source: Haiteku zeisei no kaisetsu (1993). estimates this special tax treatment could be worth \$35 million a year (Okurasho, 1991). These tax incentives are substantially larger and more widely available than the direct research support made available to the optoelectronics industry by MITI. ${ }^{6}$

Japanese optoelectronics companies can also take advantage of some accelerated tax provisions that are provided by the Japanese tax code. In common with any government-sponsored joint R\&D program, any investments made by or paid for by Japanese companies as part of the Optoelectronics Technology Research Corporation project could be depreciated $100 \%$ in the year the investment paid. This provision also governed investment made by Japanese companies in connection with MITI's Optical Measurement and Control Systems project and continues to govern investments made in connection with the Real World Computing Program (Kagaku gijutsu hakusho heisei go-nen, 1993). ${ }^{22}$

\section{COMPARISON WITH US GOVERNMENT FUNDING}

Insofar as aggregate fiscal support is concerned, there appears to be little basis for the view firmly expressed by US optoelectronics firms that Japanese government financial aid has played a critical role in the development of Japanese optoelectronics. As can be seen from Table 5(a), the total of 15 years of government direct grants and tax expenditures on behalf of the Japanese optoelectronics industry is less than what the US government provides the American industry in a single year. While US government support accounts for an average of $24.2 \%$ of US company research and development spending on optoelectronics, no more than $0.9 \%$ of Japanese company research and development is financed by the Japanese government. To be sure, as Table 5(b) shows, over $90 \%$ of US government aid is defenserelated. Much of this funding, however, appears to have direct commercial relevance. Respondents to the Department of Commerce survey reported there was a great deal of applicability of their defensefunded optoelectronics research and development to the commercial sector. Many supply similar or identical products to both military and non-military applications; others said that while their products were currently geared toward defense needs, the technologies were intended to be dual use (e.g. flightby-light for use in civilian aerospace applications, 
Table 5.

\begin{tabular}{lrrrrr}
$\begin{array}{l}\text { (a) Optoelectronics } \\
\text { (\$ million) }\end{array}$ \& spending by & US firms & $1989-93$ & \\
Source of funding & 1989 & \multicolumn{1}{c}{1990} & \multicolumn{1}{c}{1991} & 1992 & \multicolumn{1}{c}{1993} \\
In-house & $\$ 533.5$ & $\$ 598.9$ & $\$ 651.3$ & $\$ 617.7$ & $\$ 619.8$ \\
Federal government & 189.7 & 200.1 & 204.8 & 178.6 & 219.7 \\
Customer & 8.7 & 11.6 & 15.3 & 17.1 & 20.4 \\
Joint venture & 0.5 & 2.5 & 7.8 & 0.4 & 5.2 \\
Other & 3.2 & 2.2 & 3.5 & 3.0 & 2.6
\end{tabular}

(b) US government-funded research and development by funding organization

\begin{tabular}{lrrrrr} 
DOD & $\$ 122.0$ & $\$ 120.0$ & $\$ 116.6$ & $\$ 107.8$ & $\$ 145.6$ \\
ARPA & 4.5 & 6.7 & 9.0 & 22.5 & 21.7 \\
Armed Services & 48.1 & 55.3 & 57.5 & 33.3 & 38.1 \\
(Navy, Army, & & & & & \\
Air Force) & & & & & \\
NASA & 10.7 & 12.7 & 15.0 & 8.0 & 5.9 \\
DOE/Natl. Lab. & 2.4 & 1.6 & 1.5 & 0.7 & 0.3 \\
NIH & 0.6 & 0.6 & 1.1 & 1.2 & 1.0 \\
NSF & 0.3 & 0.4 & 0.4 & 0.3 & 0.3 \\
NIST & - & - & - & 0.9 & 3.1 \\
Other & 1.4 & 2.0 & 2.2 & 2.4 & 3.6 \\
\hline
\end{tabular}

Source: US Department of Commerce (1994).

military sensor work converted to production automation, industrial security or medical sensors; use of FLIRs for border control, drug interdiction, and law enforcement). In general, firms reported that they could not afford to maintain the same level of funding of research and development for commercial applications without government support. As one firm put it, 'the DoD pays for new product development, commercial customers do not' (US Department of Commerce, 1994).

\section{EVALUATING THE IMPACT OF JAPANESE GOVERNMENT PROGRAMS ${ }^{7}$}

It is possible that the small size of tax expenditures and direct grants provided by the Japanese government to promote optoelectronics may miss the forest for the trees. The total amount and terms of government aid may be less important than that such aid is given at all. Government aid may signal Japan's financial system that optoelectronics is a particularly promising area worthy of support. While this may be an accurate description of the role the Japanese government played in the 1950s, 1960s and 1970s when Japanese capital markets were severely repressed, today, the deregulation of Japan's financial system, while far from complete, has very likely removed both the need and the means by which the Japanese government might intervene. ${ }^{8}$

Quite apart from the atrophying of the Japanese government's technology policy instruments, its cues may also be taken less seriously than before because of the highly uncertain environment within which the Japanese government now operates. With Japan at the technological frontier, unlike the 1950s, 1960s and 1970s, the precise direction an industry such as optoelectronics should follow is by no means clear. In this environment, there's certainly no generic reason to believe that the government might be better informed as to which way to go than the private sector.

An excellent illustration of the difficulties the government has faced are the apparent reactions of Japanese firms to the various joint government business cooperative research and development projects organized by MITI in optoelectronics and related fields in the late 1970s, 1980s and 1990s. Japanese government-sponsored consortia were once viewed as crucial instruments of government policy, breaking down barriers to the interfirm transfer of information created by Japanese permanent employment practices, even while internalizing the benefits of company-conducted basic research. ${ }^{9}$ In contrast, the ORJL, the OTRC and the RWC program all are said to be viewed by industry as extremely academic activities, far removed from the efforts needed to help develop technologies and products for emerging markets in optoelectronics.

Because MITI's optoelectronics projects have been viewed as largely academic, member companies have been reluctant to allow their best scientists and engineers to participate in any major way. Scientists and engineers that are participating apparently have been discouraged from intimate cooperation with scientists and engineers from other member companies. Of 207 patents filed in connection with these three projects, only 34 reflect collaborative work across two or more member companies. Moreover, fearing that MITI-sponsored cooperative R\&D projects are more efforts to diffuse existing information than to create new knowledge, optoelectronics industry leaders in any particular technology have rarely chosen to take up topics in their areas of greatest expertise.

That the Japanese optoelectronics industry finds MITI's role as marginal at best and more likely a nuisance makes for an astonishing difference in perception between Japanese optoelectronics companies and American optoelectronics companies re- 
garding the role the Japanese government plays in shaping the industry. The possibility that self-interest accounts for this major difference in evaluating the role of the Japanese government is very real. The American optoelectronics industry has been attempting to maintain American government support for its research and development in the face of US Department of Defense and US Department of Commerce cutbacks. For its part, in the presence of a steady stream of trade disputes between Japan and the United States, the Japanese optoelectronics industry may be reluctant to admit, notwithstanding the relatively permissive new WTO rules in this area, that the Japanese government supports anything other than highly academic projects. ${ }^{10}$

In the interest of helping to resolve this issue it may be useful to observe what is done in the American and Japanese optoelectronics industries rather than what is said. Some help in this connection can be gained by examining whether the organization of a Japanese government-sponsored cooperative $\mathrm{R} \& \mathrm{D}$ program in optoelectronics results in a change in the market valuation of the equity of American and Japanese optoelectronics firms. Such an approach assumes that in Japan, as in the United States, unbiased assessments of the effects of publically released information influencing future firm profitability are systematically incorporated into publically traded equities. A list of the Japanese and American firms whose equity valuation will be studied is presented in Table 6 .

The criteria used for choosing forms for this study include the availability of regular price quotations during the event period, and firm size. Given the relatively small size of the Japanese governmentsponsored optoelectronics projects, under any reasonable assumptions about the centrality of these activities for the future of optoelectronics, there is little point in examining whether they had any impact

\section{Table 6. Japanese and American Optoelec- tronics Firms Included in Event Study Sample}

Rohm

Tokin

Kyoritsu Ceramic Materials

Nippon Signal

Sankyo Seiki

Nippon Electric Glass

Hosiden

Hamamatsu

Hoya
Advanced Photonix

Zygo

Drexler Technology.

Oak Industries

Op telecom.

Trimedyne

Essex

Quixote

Spiae on the market valuation of the equity of the very large electronics companies that were the two governmentsponsored project's major contractors. The answer would quite likely be negligible. ${ }^{11}$ These companies are involved in too many lines of business for the influence of a government-sponsored cooperative project to have a discernible impact on the company's value in the marketplace. Examining the project's impact on smaller firms active in areas related to its major themes seems to be a fairer test.

A Japanese government-sponsored cooperative research and development if it is to have an impact on equity valuation must generate changes significantly above or significantly below those that would have been predicted given the firm's normal relationship with the market. If stock market returns follow a multivariate normal distribution, the following wellknown equation holds

$$
R_{i w}-R_{f w}=a_{i}+b_{i}\left(R_{m w}-R_{f w}\right)+v_{i w}
$$

where $R_{i w}=$ continuously compounded rate of return for security $i$ in period $w, R_{m w}=$ continuously compounded rate of return for the market portfolio, $R_{f w}=$ continuously compounded risk-free rate of return, $b_{i}=\operatorname{cov}\left(R_{i w^{*}}, R_{m w^{*}}\right) / \operatorname{var}\left(R_{m w^{*}}\right)=$ the systematic risk of security $i ; \quad R_{i w^{*}}=R_{i w}-R_{f w}$; $R_{m w^{*}}=R_{m w}-R_{f w}, \quad a_{i}=$ firm-specific constant, $v_{i w}=$ normally distributed random error term that is uncorrelated with $R_{m w}$ and has zero mean and constant variance.

Equation (1) is estimated for the eighteen Japanese and American firms listed in Table 6. This estimation takes place using weekly returns from 78 weeks before the first reports anticipating (1) the organization in 1986 of the OTRC and (2) the commencement of the optical computing portion of the RWC program in 1992 appearing in the Japanese press up until 26 weeks before such reports appeared and 26 weeks up until 78 weeks after the official announcement of each project. ${ }^{12}$ The parameters estimated from Eqn (1) are used to compute excess returns for each security for the period when new information about the organization of the OTRC and the RWC optical computing project reaches the equity markets.

$G_{i w}=\left(R_{i w}-R_{f w}\right)-\hat{a}_{i}-\hat{b}_{i}\left(R_{m w}-R_{f w}\right) \quad e_{1} \leq w \leq e_{2}$

where $\hat{a}_{i}$ and $\hat{b}_{i}$ are taken from the estimation of Eqn (1).

Just calculating excess returns for an arbitrary period $\left(e_{1}, e_{2}\right)$ preceding the announcement of the 
projects ignores the gradual leakage of information that is so characteristic of the bureaucratic decisionmaking process in Japan (Halloran, 1969). Even newspaper reports on rumors about plans for such projects may lag substantially the capitalization of such information by the equity markets. Unfortunately, if $e_{1}$ is set very far away from $e_{2}$ to allow for a lengthy period of information leakage, the test to check for statistically significant excess returns will have very low power (see, for example, Rubacker, 1982; Brown and Warner, 1980). Alternatively, assume the gradual leakage of information influences securities prices in the S-shaped pattern of the cumulative normal distribution function (Ellison and Mullin, 1995).

$$
\begin{gathered}
E\left(G_{i w} / Y_{w}\right)=g\left\{\Phi\left(\frac{w-\mu}{\eta}\right)-\Phi\left(\frac{w-1-\mu}{\eta}\right)\right\} \\
e_{1} \leq w \leq e_{2}
\end{gathered}
$$

where $g \equiv$ reaction parameter, $\Phi \equiv$ normal cumulative function with $\mu$ and $\eta$ as first and second moments, $e_{2} \equiv$ time the project is formally announced.

In order to avoid arbitrary decisions as to when information about the government-sponsored projects first influenced equity prices, $g, \mu$, and $\eta$ will be estimated using observations beginning 26 weeks before the first rumors appeared in the press up until the final official announcement of the projects and its participants are made. $g, \mu$, and $\eta$ are estimated separately both for the OTRC and the RWC project and separately for each national sample of firms. It is also assumed that while $e_{1}$ is the same for both national samples, $e_{2}$ will vary in accordance with when the announcement is made in Japanese- and English-language publications.

The results of this estimation are presented in Table 7. These results highlight the starkly different reactions of Japanese and American equity prices to information about the organization of these two optoelectronics projects. Japanese equity values have a positive statistically insignificant reaction to such information. In contrast, American equity values have a strong, statistically significant negative reaction. This is true for both projects not withstanding that unlike the OTRC, the RWC project did allow for some foreign participation. ${ }^{13}$ Indeed, as can be seen from Table 7, the reaction of American

\section{Table 7. The Impact of Government-sponsored Cooperative Optoelectronics Projects on Equity Values}

(a) $O T R C$

$\begin{array}{lc}\text { Japan } & \text { USA } \\ 0.0119 & -0.0632 \\ (0.0163) & (0.0296) \\ 32.1 & 43.6 \\ (1.62) & (2.5) \\ 4.35 & 6.2 \\ (1.14) & (1.83)\end{array}$

(b) RWC -optical computing

\begin{tabular}{cc} 
Japan & USA \\
0.0313 & -0.112 \\
$(0.0299)$ & $(0.0258)$ \\
26.2 & 30.1 \\
$(1.1)$ & $(1.4)$ \\
3.41 & 1.89 \\
$(1.07)$ & $(0.631)$ \\
\hline
\end{tabular}

Note: Standard errors are in parenthesis. $\mu$ and $\eta$ are calibrated in weeks.

equity values is still more negative to the organization of the RWC project than it is to the organization of the OTRC.

$\mu$ and $\eta$, the first two moments of the cumulative normal distribution function $\Phi$, characterize the time path of the impact of information of the organization of the OTRC and the optical computing portion of the RWC project on Japanese and American equity values. $\mu$ indicates the point in the distribution where new information about the projects has its maximum impact. $\eta$ helps characterize how quickly such information diffuses to the equity markets.

Unlike the reaction parameter $g, \mu$ and $\eta$ are statistically significant for both the Japanese and American samples. Information about the organization of the ORTC has its maximum impact on Japanese equity values a mere six weeks after initial press reports about the ORTC and over four months before an official announcement finally appeared. Ninety per cent of the information about this project diffused in Japan between one and a-half and ten and a half weeks after the first press reports. As Table 7 indicates, $90 \%$ of information about the organization of the ORTC had diffused to Japanese security markets before $10 \%$ of such information had reached American markets. Ninety per cent of information about the organization of the OTRC diffused to American security markets only some three and a half months later. Eight years later the diffusion of information about optoelectronics was much faster. Ninety per cent of the information about the optical computing portion 
of the RWC project reached American equity markets only two and a half weeks after $90 \%$ of this information had reached Japanese markets. Significantly, 90\% of this information had reached American markets only six weeks after the very first Japanese press reports began appearing on the RWC project. It appears American monitoring of Japanese press has improved significantly in recent years.

In light of the results for Japanese equity values, it is certainly surprising to discover that information on the organization of Japanese optoelectronics projects has a negative impact on selected American equities. These results are consistent, however, with the contrasting perceptions of the importance of these projects in the United States and Japan. Apparently, American equity values reflect the belief that these projects, directly or indirectly, will give Japanese firms a competitive edge in global markets. In contrast, the movement of Japanese equity values suggest these projects, both directly or indirectly, have little significance for the commercial success of Japanese firms in the forseeable future. The analysis undertaken here does not suggest which perception is correct. ${ }^{14}$ If Japanese markets are better informed than American markets as to the significance of these projects, the Japanese government policy may be unintentionally deterring some foreign entry into this industry or it may be getting the benefits of some strategic deterrence on the cheap. ${ }^{15}$

\section{FINALE}

The Japanese government is not longer, if it ever was, a major source of support for the development of new technologies. Where once the Japanese government signaled the private sector about the direction incremental investment might take, with financial deregulation and technological maturity, this role is no longer either possible or necessary. The same technological maturity that makes signaling to the private sector so difficult has made even a coordinating role for the Japanese government troublesome. Ironically, equity market evidence is consistent with the conflicting positions taken by the American and Japanese optoelectronics industries on the role the Japanese government plays in creating a favorable business environment.

\section{NOTES}

1. US Department of Commerce (1994, p. IV-26). Anode glass, glass rod, core glass and cladding glass all come from three basic sources: Corning/Dow Corning (USA), Schott Glass (Germany and the USA) and Heraeus Amersil (Germany).

2. In this connection, it should be noted that alumni of Bell Labs and MITI are both very prominent in Japan's optoelectronics industry (Nikon keizai shimbun, 10 October, 1987 and 19 November, 1988). Recently, some Japanese firms have attempted to cement relationships with American universities by financing endowed chairs in optoelectronics-related fields. For example, Hitachi has endowed positions at MIT and at the University of Illinois.

3. The Science and Technology Agency, the Ministry of Education and the Ministry of Post and Telecommunications all oversee significant optoelectronics research programs. The Science and Technology Agency sponsors research at its own National Research Institute for Metals and at the Research Development Corporation of Japan, while the Ministry of Education provides for grants for optoelectronics research at Japan's future fiber-optical network and sponsors optoelectronic research at its affiliated Communications Research Laboratory and at the Japan Key Technology Center. See the description of these activities provided in Kagaku gijutsu hakusho heisei go-nen (1993). These programs most resemble the academic programs of the US National Science Foundation and research at the National Bureau of Standards laboratories.

4. This project focuses on the technology and application of ultrafast laser pulses on the femtosecond time scale ( 1 femtosecond $=10^{-15}$ second).

5. Having a single year as the base is a disadvantage on the assumption that research and development expenditures are regularly increasing.

6. Unlike the Japanese semiconductor industry, there is little evidence that the Japanese optoelectronics industry benefits in any significant special way from the generally unexceptional accelerated depreciation provision of the Japanese tax code. See Okamoto, Miyamoto and Sakurai (1988).

7. As in the United States, so in Japan, the greatest impact that government policy will have on the development of optoelectronics may be in the area of telecommunications policy. For example, in February 1995 the Japanese government announced its intention to complete a nationwide fiber-optic network by 2010 . The regulatory reform of telecommunications in Japan will also shape the optoelectronics industry.

8. In the 1950s, 1960s and even the 1970s, a signal from the Japanese government compensated for a lack of information that might otherwise be provided by freely functioning capital markets. With Japan's financial system highly concentrated and heavily regulated, its equity markets played too marginal a role in the allocation of resources to serve as the ultimate arbiter of future prospects. High concentration and heavy regulation, particularly of entry, provided a framework within which the Japanese government, through the financial system could influence the allocation of resources. High concentration made a government presence not only possible but necessary. Moreover, 
as long as Japan was far from the global economy's technological frontier, fathoming what structural change the Japanese economy required was not difficult. At the same time, however, the complicated pressures of intra-keiretsu or bank group politics often meant that in the absence of government pressure a socially suboptimal allocation of resources might easily result. Without government, it was too easy for established industries to divert badly needed resources from emerging industries.

9. At the very peak of their importance and influence projects such as MITI's celebrated Very Large Scale Integration (VLSI) semiconductor consortium were viewed, accurately or otherwise, as playing a critical role in helping diverse Japanese companies to coordinate their research. Duplication of effort was avoided and information that might otherwise have been considered proprietary was shared. For further discussion, see Saxonhouse (1992a, b).

10. It is possible that in the interest of strategically deterring foreign entry the Japanese industry might want to suggest just the opposite.

11. Note the discussion in Nihon keizai shimbun, 11 December, 1984 and 25 December, 1984, as to the impact of optoelectronics on equities quoted on the Tokyo Stock Exchange.

12. Lack of availability of data prevents an event study of the 1979 Optical Measurement and Control Systems project.

13. Yomiuri Shimbun (17 November, 1992). The joint US and Japanese component of the Real World Computing project was only begun, however, some two and onehalf years after Real World Project was first announced (The United States Department of Commerce News, 26 January, 1995). This joint project may to some extent have been induced by the initial negative reaction of the American optoelectronics industry to the Real World Computer project.

14. It is possible both perceptions are correct. For example, many firms in Japan may have benefited by the government-sponsored optoelectronics projects but not the particular firms in the samples analyzed here. Note that despite the increasing integration of Japanese and American equity markets, the presence of homecountry bias in portfolio selection allows for nationspecific perception that need not be arbitraged away. See Frankel (1993).

15. It is possible such a strategic deterrence policy may backfire by stimulating US government support for its optoelectronics industry. According to the Far Eastern Economic Review (25 June, 1992), MITI's Fifth Generation computer project stimulated far larger, artificial intelligence projects in the United States and Europe.

\section{REFERENCES}

S. J. Brown and J. B. Warner (1980). Measuring security price performance. Journal of Financial Economics. September.
The Economist (1991). The optical enlightenment. 6 July, 87.

S. F. Ellison and W. B. Mullin (1995). Economics and politics: the case of sugar tariff reform. Journal of Law and Economics, 38, No. 5, October.

J. A. Frankel (1993). The internationalization of equity markets. National Bureau of Economic Research, Working Paper No. 4590.

G. M. Grossman (1990). Promoting new industrial activities: a survey of recent arguments and evidence, OECD Economic Studies, 14, Spring, 87-125.

R. Halloran (1969). Japan: Images and Realities, New York: Knopf.

I. Hayashi, M. Hirano and K. Yoshifumi (1989). Collaborative semiconductor research in Japan. Proceedings of the IEEE, 77, No. 9, September.

Hikari sangyo no doko, (1994), Hikari sangyo gijutsu shinkokai, Tokyo, pp. I-18-I-32.

Kagaku gijutsu hakusho heiseu go-nen (1993). Kagaku gijutsu cho, Tokyo.

P. R. Krugman (1987). Strategic sectors and international competition. In U.S. Trade Policies in a Changing World Economy. (edited by R. M. Stern), Cambridge, MA: MIT Press.

A. Mas-Colell, M. D. Whinston and J. R. Green (1995). Microeconomic Theory, (New York: Oxford University Press) Chapters 11-14.

K. Okamoto, M. Miyamoto and M. Sakurai (eds) (1988). Haitekku kaikei, Tokyo: Doyukan.

Okurasho, Genka shokyaku shisan to taiyonensu-to ni kansuru shorei (1991). (Tokyo).

Optoelectronics Industry Development Association (1994). Technology Roadmaps for Optoelectronics 1993-2012, Washington, DC.

Real World Computing Partnership (1994). Synopsis of Research, Tokyo.

R. S. Ruback (1982). The effect of discretionary price decisions on equity values. Journal of Financial Economics, 9, No. 1, March.

G. R. Saxonhouse (1983). The micro- and macroeconomics of foreign sales to Japan. In Trade Policy in the 1980s (edited by William Cline) Cambridge, MA: MIT Press for the Institute for International Economics.

G. R. Saxonhouse (1992). Japanese high technology, government policy and evolving comparative advantage. In Industrial Policy and International Trade (edited by V. A. Canto and J. K. Dietrich), Greenwich, CT: JAI Press.

G. R. Saxonhouse (1993). What's all this about Japanese technology policy? Regulation, 16, No. 6, Fall.

P. Seidenberg (1992). The New Optoelectronics Ball Game. New York: IEEE Press.

Sangyo zeisei handobukku (1994). Tsushonsangyosho, Tokyo.

US Department of Commerce, Bureau of Export, Administration, Office of Industrial Resource Administration, Strategic Analysis Division (1994). Critical Technology Assessment of the US Optoelectronics Industry, Washington, DC. 